\title{
PENGEMBANGAN MODUL PENYUSUNAN PROGRAM BIMBINGAN DAN KONSELING KOMPREHENSIF DI SEKOLAH MENENGAH KEJURUAN
}

\author{
Nindiya Eka Safitri ${ }^{1}$ \\ ${ }^{1}$ Bimbingan dan Konseling, SMK Muhammadiyah Wonosari \\ nindiya26@gmail.com
}

\begin{abstract}
Abstrak
Penelitian ini bertujuan untuk mengembangkan modul penyusunan program bimbingan dan konseling komprehensif di Sekolah Menengah Kejuruan. Jenis penelitian yang digunakan adalah $\mathrm{RnD}$ dengan model 4D (Define, Design, Development dan Dissemination). Subjek penelitian adalah guru BK SMK Negeri di se-Kota Yogyakarta yang telah bersertifikat (purposive sampling), sejumlah 25 orang. Instrumen terdiri dari lembar pengamatan dan tes pemahaman yang divalidasi oleh ahli (expert judgement). Untuk uji ahli materi dan media menggunakan instrumen lembar pengamatan ahli. Sedangkan uji coba produk instrument lembar penilaian pengguna produk. Untuk menguji efektivitas produk, maka diberikan tes pemahaman materi. Hasil uji ahli media memperoleh skor sebesar 73,44 dengan kategori "Baik". Hasil uji ahli materi memperoleh skor sebesar 86,85 dengan kategori "Sangat Baik". Sedangkan hasil uji coba lapangan (uji keterbacaan modul) memperoleh skor 80 dengan kategori "Sangat Baik". Hasil uji efektifitas modul menunjukkan adanya peningkatan pemahaman guru sebesar 1,52. Hasil konsultasi dengan tabel distribusi $t$ diperoleh perbandingan $t_{0,05}<\mathrm{t}_{0,01}<\mathrm{t}$, yaitu $2,08<2,80<5,60$. Perbandingan ini memiliki arti bahwa penggunaan modul memiliki pengaruh positif (signifikan) baik pada taraf signifikansi $t_{0,05}$ maupun taraf signifikansi $\mathrm{t}_{0,01}$. Hal ini menunjukkan bahwa pengembangan modul telah terlaksana dan efektif dalam meningkatkan pemahaman guru BK dalam menyusun program BK komprehensif di SMK.
\end{abstract}

Kata Kunci: Bimbingan dan Konseling, Komprehensif, SMK

\begin{abstract}
This research aims to develop modules drafting a comprehensive guidance and counseling program in Vocational High School. This type of research is the research and development. The subjects were guidance and counseling teachers at SMK as the city of Yogyakarta that has been certified (purposive sampling), some 25 people. The instruments used consist of sheets of observation and comprehension tests were validated by an expert (expert judgment). To test the material and media experts using expert observation sheet instruments. While testing instrument products sheet product user ratings. To test the effectiveness of the product, then given a comprehension test material. Media expert test results given a score of 73.44 in the category of "Good". The test results matter experts given a score of 86.85 with the category of "Very Good". While the results of field trials (legibility test module) received a score of 80 in the category of "Very Good". The effectiveness of the module test results showed an increase teacher understanding of 1.52. result consultation with the $t$ distribution table for the comparison of $\mathrm{t}_{0.05}<\mathrm{t}_{0.01}<\mathrm{t}$, namely $2.08<2.80<5.60$. This comparison has meant that the use of the modules has a positive influence (significant) whether or ${ }_{0.05}$ significance level $\mathrm{t} \mathrm{t}_{0.01}$ significance level. This suggests that the development of the module has been accomplished and effective in improving the understanding of guidance and counseling teachers in drafting a comprehensive guidance and counseling program at VHS.
\end{abstract}

Keywords: Guidance and Counseling, Comprehensive, Vocational High School 


\section{PENDAHULUAN}

Saat ini telah terjadi perubahan paradigma pendekatan bimbingan dan konseling, yaitu dari pendekatan yang berorientasi tradisional, remedial, klinis, dan terpusat pada konselor kepada pendekatan yang berorientasi perkembangan dan preventif. Sebagaimana pendapat Sutoyo, dkk (2015: 48) bahwa BK perkembangan berbicara "fokus" atau pusat perhatian membantu perkembangan potensi, sedangkan BK komprehensif bicara "cakupan aspek" yang dikembangkan yang menyeluruh (komprehensif), artinya bukan hanya aspek jasmani saja, atau rohani saja, tetapi menyeluruh". Orientasi dari BK perkembangan adalah terwujudnya perkembangan yang optimal pada diri siswa. Sitti \& Caraka (2016: 270) menyatakan bahwa "optimum development is not limited to the achievement of achievement in accordance with the intellectual capacity and interest, but as a developmental condition that allow leaners are able to make choice and decisions in responsibility and adaptability to the dynamics of their life."

Model bimbingan dan konseling berorientasi perkembangan dan preventif disebut juga dengan bimbingan dan konseling komprehensif. Model program bimbingan dan konseling komprehensif mulai berkembang di beberapa negara maju di Amerika Serikat semenjak tahun 1970-an.
Adapun model bimbingan komprehensif sendiri menurut Gysbers dan Henderson (2012: 62) adalah "A comprehensive guidance and counseling program is a program as having a common language organizational framework with a spesific configuration of planned, sequenced, and coordinated guidance and counseling activities and services based on student, school, and community needs and resources, designed to serve all students and their parents or guardians in a local school district." Kaitannya dengan bimbingan dan konseling komprehensif, pemerintah Indonesia telah mengeluarkan Peraturan Menteri Pendidikan Nasional Nomor 27 Tahun 2008 tentang Standar Kualifikasi Akademik dan Kompetensi Konselor. Dalam permendiknas ini dijelaskan bahwa guru $\mathrm{BK} /$ konselor dituntut untuk dapat merancang dan mengimplementasikan program bimbingan dan konseling yang komprehensif. Tuntutan ini sebagaimana dijelaskan pada butir D nomor 13 yang meliputi: (a) menganalisis kebutuhan konseli; (b) menyusun program bimbingan dan konseling berkelanjutan berdasarkan kebutuhan peserta didik secara komprehensif dengan pendekatan perkembangan; (c) menyusun rencana pelaksanaan program bimbingan dan konseling; serta (d) merencanakan sarana dan biaya 
penyelenggaraan program bimbingan dan konseling.

Hal tersebut sesuai dengan standar yang ditentukan oleh Council for Accreditation of Counseling and Related Educational Program (CACREP) tahun 2009 dalam Dollarhide (2012: 3) bahwa konselor sekolah harus mampu merancang, mengimplementasikan dan mengevaluasi program bimbingan dan konseling komprehensif; merancang kegiatan untuk memfasilitasi peserta didik mengembangkan kompetensi akademik, karir dan pribadi-sosial; serta mengetahui dasar hukum dan kode etik dalam praktek konseling di sekolah. Dalam Permendikbud Nomor 111 Tahun 2014 tentang Bimbingan dan Konseling Pada Pendidikan Dasar dan Pendidikan Menengah. Permendikbud juga telah memberikan pedoman bagi penyelenggaraan layanan bimbingan dan konseling di pendidikan dasar dan menengah dengan menggunakan program bimbingan dan konseling komprehensif.

Saat ini, guru BK/konselor dituntut untuk memahami secara lebih mendalam tentang konsep dasar teoritis dan praksis bimbingan dan konseling komprehensif termasuk cara penyusunan program bimbingan dan konseling komprehensif sesuai dengan tugas perkembangan peserta didik pada jenjang sekolah tertentu. Proses kegiatan penyusunan program bimbingan dan konseling komprehensif sangat panjang. Guru BK/konselor di sekolah perlu memahami langkah-langkah atau prosedur penyusunan program bimbingan dan konseling komprehensif.

Untuk jenjang Sekolah Menengah Kejuruan (SMK), penyusunan program bimbingan dan konseling komprehensif memiliki karakteristik tersendiri. Sebagaimana dijelaskan dalam Permendikbud Nomor 70 Tahun 2013 tentang Kerangka Dasar dan Struktur Kurikulum SMK/MAK, bahwa peserta didik di tingkat SMK dididik agar siap untuk langsung bekerja di dunia kerja. Pendidikan di SMK difokuskan pada pengembangan minat dan potensi diri melalui berbagai program keahlian yang ditawarkan di sekolah menengah kejuruan. Dengan demikian, penyusunan program bimbingan dan konseling komprehensif di SMK hendaknya lebih mengarah pada penyiapan lulusan yang siap kerja.

Faktanya, sebagian guru BK/konselor di tingkat SMK belum memahami secara utuh konsep dasar dan cara penyusunan program bimbingan konseling komprehensif. Hasil penelitian Hesty Nurrahmi (2015) tentang kompetensi guru BK tingkat SMK di Pontianak dalam merancang program juga menunjukkan bahwa guru BK tingkat SMK dalam merancang program berada pada kategori kurang 
menguasai $(52,63 \%)$. Masih ditemui guru bimbingan dan konseling yang belum memiliki kemampuan optimal dalam menyelenggarakan program bimbingan dan konseling terutama dalam merancang dan menyusun program bimbingan dan konseling. Sementara itu, hasil penelitian Juli Wantoro (2016) tentang profil tingkat pemahaman guru BK di SMK Negeri se-kota Yogyakarta dalam penyusunan program bimbingan dan konseling komprehensif menunjukan bahwa profil tingkat pemahaman guru BK di SMK Negeri se-kota Yogyakarta dalam penyusunan program BK komprehensif secara keseluruhan menunjukan kategori sedang, yaitu sebanyak 14 guru (50\%), jika dilihat dari masingmasing aspek. Profil tingkat pemahaman guru bimbingan dan konseling dalam penyusunan program BK komprehensif adalah aspek 1 berada pada kategori sedang yaitu sebanyak 14 guru (50\%), aspek 2 berada pada kategori sedang yaitu sebanyak 24 guru $(85,7 \%)$, aspek 3 berada pada kategori tinggi yaitu sebanyak 17 guru $(60,7 \%)$, aspek 4 berada pada kategori rendah yaitu sebanyak 17 guru $(60,7 \%)$ dan aspek 5 berada pada kategori sedang yaitu sebanyak 12 guru $(42,9 \%)$.

Berdasarkan beberapa hasil penelitian di atas, diketahui bahwa kemampuan guru BK/konselor di SMK dalam menyusun program bimbingan dan konseling komprehensif belum maksimal. Perlu adanya usaha untuk meningkatkan kemampuan guru BK tingkat SMK dalam menyusun program bimbingan dan konseling komprehensif. Oleh karena itu, penulis tertarik untuk mengembangkan modul sebagai pedoman penyusunan program bimbingan dan konseling komprehensif, khususnya untuk tingkat Sekolah Menengah Kejuruan (SMK).

\section{METODE PENELITIAN}

Jenis penelitian yang digunakan adalah penelitian dan pengembangan atau Research and Development $(\mathrm{RnD})$ dengan model 4D (Define, Design, Development dan Dissemination). Prosedur penelitian model ini meliputi tahap define (pendefinisian), design (perancangan), development (pengembangan), dan dessimination (penyebarluasan) (Endang, 2011).

Peneliti melaksanakan penelitian di seluruh SMK Negeri seKota Yogyakarta, pada bulan Desember sampai dengan Maret 2017. Sedangkan, subjek dalam penelitian adalah guru BK SMK Negeri di se-Kota Yogyakarta yang telah bersertifikat (purposive sampling), sejumlah 25 orang. Objek penelitian ini adalah tentang pengembangan modul penyusunan program bimbingan dan konseling komprehensif di SMK.

Adapun prosedur penelitian ini mengikuti langkah pelaksanaan $\mathrm{RnD}$ 
berdasarkan model 4D, yaitu sebagai berikut;

1. Define (pendefinisian)

Menganalisis kebutuhan produk yang akan dikembangkan, yaitu dengan melakukan studi pendahuluan (wawancara) dengan guru BK SMK se-Kota Yogyakarta

2. Design (perancangan)

Menentukan dan membuat rancangan produk awal, yaitu membuat desain sampul dan kerangka isi modul, serta mengembangkan instrument pengampilan data

3. Development (pengembangan)

Mengembangkan produk sembari, lalu melakukan uji ahli (ahli media dan materi) dan melakukan uji coba produk (calon pengguna produk). Setelah itu, juga melakukan perbaikan sesuai saran ahli dan calon pengguna produk

4. Dessimination (penyebarluasan)

Mensosialisasikan hasil

pengembangan produk akhir

Sementara itu, teknik pengumpulan data yang digunakan dalam uji ahli adalah teknik non tes, berupa lembar pengamatan. Instrumen ini untuk menguji kualitas modul dari segi media dan materi. Teknik pengumpulan data lain yang digunakan adalah teknik tes, berupa tes pemahaman berbentuk multiple choice dengan 4 (empat) alternatif jawaban. Instrumen ini untuk mengetahui efektivitas pengembangan modul dalam mengembangkan pemahaman guru
BK dalam menyusun program bimbingan dan konseling komprehensif. Sedangkan teknik analisis data yang digunakan menggunakan teknik analisis data deskriptif kuantitatif.

\section{HASIL DAN PEMBAHASAN}

Penelitian diawali dengan kegiatan menganalisis kebutuhan produk yang akan dikembangkan. Hasil analisis kurikulum mengungkapkan bahwa SMK Negeri di Yogyakarta sebagian besar telah mengacu pada kurikulum 2013 dan menggunakan model program bimbingan dan konseling komprehensif dengan berlandaskan pada Permendikbud Nomor 111 Tahun 2014 tentang Bimbingan dan Konseling Pada Pendidikan Dasar dan Menengah. Dimana di dalam lampiran permendikbud ini, guru BK dituntut untuk dapat menyusun program bimbingan dan konseling komprehensif yang terdiri dari 10 (sepuluh) struktur program, yaitu rasional, visi dan misi, deskripsi kebutuhan, tujuan layanan, komponen layanan, bidang layanan, pengembangan tema/topik, evaluasi, pelaporan dan tindak lanjut, anggaran biaya dan rencana kegiatan (action plans). Hasil analisis karakteristik pengguna produk mengungkapkan guru BK bahwa membutuhkan media cetak berupa bacaan yang disertai dengan contohcontoh agar dapat menyusun program bimbingan dan konseling. Sedangkan analisis materi relevan 
dengan substansi yang terdapat dalam Lampiran Permendikbud No. 111 Tahun 2014 tentang Bimbingan dan Konseling Pada Pendidikan Dasar dan Pendidikan Menengah, terutama tentang materi struktur program BK komprehensif. Sementara itu, berdasarkan hasil analisis di atas, peneliti merumuskan bahwa tujuan pembelajaran modul tersebut adalah untuk meningkatkan pemahaman dan kemampuan guru BK di SMK dalam menyusun program bimbingan dan konseling komprehensif secara mandiri, serta secara baik dan benar.

Selanjutnya, penelitian dilanjutkan dengan kegiatan design (perancangan) draft awal modul. Draft awal modul meliputi desain sampul depan dan belakang, struktur modul dan rancangan penulisan materi. Desain sampul modul dibuat dengan menggunakan aplikasi desain grafis, yaitu Corel Draw X7, sedangkan pengetikan isi modul menggunakan Microsoft Word 2013. Adapun konten yang terdapat pada sampul depan modul itu sendiri terdiri dari tulisan judul modul, nama penulis, nama instansi/lembaga penulis dan sejumlah gambar hidup yang relevan dengan judul modul. Sedangkan untuk sampul belakang modul berisi biografi penulis.

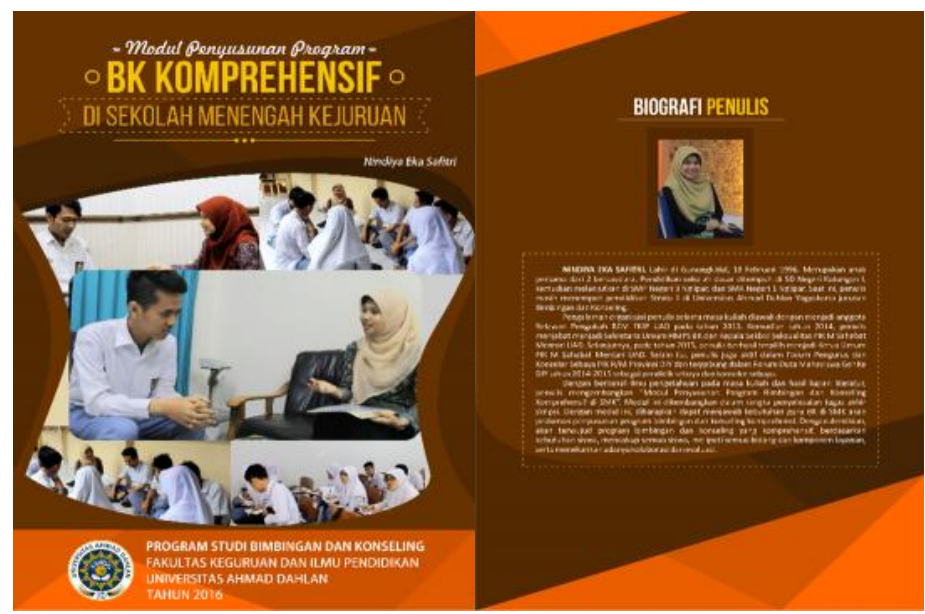

Gambar 1. Desain Sampul Depan dan Belakang Modul

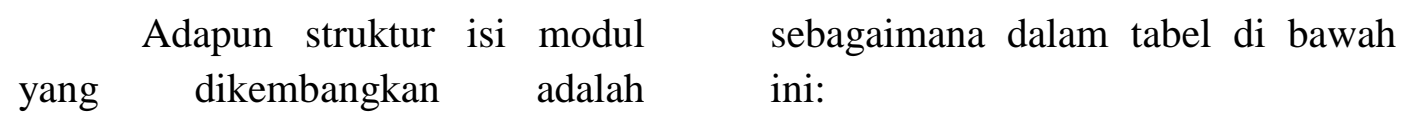

Tabel 1.

Struktur Modul Penyusunan Program BK Komprehensif

\begin{tabular}{clrl}
\hline BAGIAN & \multicolumn{2}{c}{ MATERI } & \\
\hline I & Konsep Dasar Program & 1. Program Bimbingan dan Konseling Komprehensif \\
& $\begin{array}{c}\text { Bimbingan } \\
\text { Konseling Komprehensif }\end{array}$ & & dan \\
& 2. Struktur Program Bimbingan dan Konseling Komprehensif \\
\hline II & Pengembangan Rasional & 1. Konsep Pengembangan Rasional \\
\hline
\end{tabular}




\begin{tabular}{|c|c|c|}
\hline & & 2. Contoh Pengembangan Rasional \\
\hline III & $\begin{array}{l}\text { Pengembangan Visi dan } \\
\text { Misi Bimbingan dan } \\
\text { Konseling }\end{array}$ & $\begin{array}{l}\text { 1. Konsep Pengembangan Visi dan Misi Bimbingan dan } \\
\text { Konseling } \\
\text { 2. Petunjuk Pengembangan Visi dan Misi Bimbingan dan } \\
\text { Konseling }\end{array}$ \\
\hline IV & $\begin{array}{l}\text { Pengembangan Deskripsi } \\
\text { Kebutuhan }\end{array}$ & $\begin{array}{l}\text { 1. Konsep Deskripsi Kebutuhan } \\
\text { 2. Contoh Analisis Kebutuhan Siswa } \\
\text { 3. Pengembangan Deskripsi Kebutuhan Layanan }\end{array}$ \\
\hline $\mathrm{V}$ & $\begin{array}{l}\text { Pengembangan Tujuan } \\
\text { Layanan Bimbingan dan } \\
\text { Konseling }\end{array}$ & $\begin{array}{l}\text { 1. Konsep Tujuan Layanan Bimbingan dan Konseling } \\
\text { 2. Pengembangan Tujuan Layanan Bimbingan dan Konseling }\end{array}$ \\
\hline VI & $\begin{array}{lr}\text { Pengembangan } & \\
\text { Komponen } & \text { Program } \\
\text { Bimbingan } & \text { dan } \\
\text { Konseling } & \\
\end{array}$ & $\begin{array}{l}\text { 1. Hakikat Komponen Program Bimbingan dan Konseling } \\
\text { 2. Petunjuk Pembagian Prosentase Komponen Program } \\
\text { Bimbingan dan Konseling }\end{array}$ \\
\hline VII & $\begin{array}{l}\text { Pengembangan Bidang } \\
\text { Layanan Bimbingan dan } \\
\text { Konseling }\end{array}$ & $\begin{array}{l}\text { 1. Konsep Pengembangan Bidang Layanan Bimbingan dan } \\
\text { Konseling } \\
\text { 2. Petunjuk Pengklasifikasian Bidang Layanan Bimbingan } \\
\text { dan Konseling }\end{array}$ \\
\hline VIII & $\begin{array}{l}\text { Pengembangan } \\
\text { Tema/Topik Layanan }\end{array}$ & $\begin{array}{l}\text { 1. Konsep Dasar Pengembangan Tema/Topik Layanan } \\
\text { 2. Petunjuk Pengembangan Tema/Topik dalam RPLBK }\end{array}$ \\
\hline IX & $\begin{array}{l}\text { Pengembangan Evaluasi, } \\
\text { Pelaporan dan Tindak } \\
\text { Lanjut }\end{array}$ & $\begin{array}{l}\text { 1. Konsep Dasar Evaluasi, Pelaporan dan Tindak Lanjut } \\
\text { 2. Petunjuk Pengembangan Laporan Hasil Kegiatan }\end{array}$ \\
\hline$X$ & $\begin{array}{l}\text { Pengembangan Anggaran } \\
\text { Biaya }\end{array}$ & $\begin{array}{l}\text { 1. Konsep Anggaran Biaya } \\
\text { 2. Petunjuk Pengembangan Anggaran Biaya }\end{array}$ \\
\hline XI & $\begin{array}{l}\text { Pengembangan Rencana } \\
\text { Kegiatan (Action Plans) }\end{array}$ & $\begin{array}{l}\text { 1. Konsep Pengembangan Rencana Kegiatan Petunjuk } \\
\text { 2. Pengembangan Rencana Kegiatan (Action Plans) }\end{array}$ \\
\hline
\end{tabular}

Setelah diperoleh rancangan, maka segera berlanjut pada kegiatan develop (pengembangan). Jenis kertas yang digunakan sebagai sampul modul adalah kertas Ivory 260 ukuran B5 (25,7x18,2 cm). Sedangkan jenis kertas untuk bagian isi modul adalah kertas HVS 80 gram ukuran B5 (25,7x18,2 cm). Pencetakan modul menggunakan printer HP Laser Jet Seri 1102 Full Colour. Setelah diperoleh modul cetak, dilakukan uji ahli media oleh dosen ahli media bimbingan dan konseling, serta uji ahli materi oleh dosen ahli manajemen bimbingan dan konseling. Berikut ini adalah grafik yang hasil analisis uji ahli media dan uji ahli materi terhadap modul penyusunan program bimbingan dan konseling komprehensif di SMK.

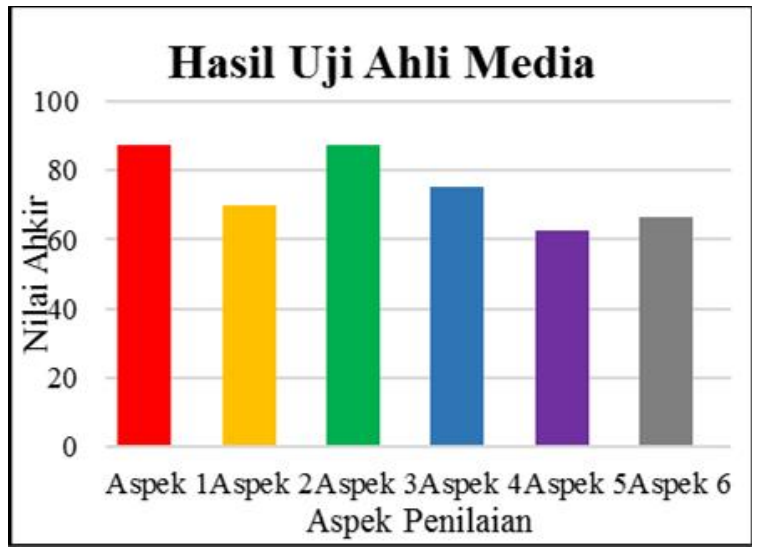

Grafik 1. Hasil Uji Ahli Media 
Berdasarkan grafik di atas, diperoleh keterangan bahwa hasil uji ahli media pada aspek 1 (aspek format) memiliki nilai 87,5 berada pada kategori "Sangat Baik", pada aspek 2 (aspek organisasi) memperoleh nilai 70 berada pada kategori "Baik", pada aspek daya tarik (aspek 3) memperoleh nilai 87,5 berada pada kategori "Sangat Baik", pada aspek 4 (aspek bentuk dan huruf) memperoleh nilai 75 berada pada kategori "Baik", pada aspek 5 (aspek spasi kosong) memperoleh nilai 62,5 berada pada kategori "Baik", dan pada aspek 6 (aspek konsistensi) memperoleh nilai 66,67 berada pada kategori "Baik". Sementara itu, diketahui bahwa nilai akhir dari uji ahli media adalah sebesar 73,44, atau berada pada rentang nilai 51-76 sehingga termasuk dalam kategori "Baik".

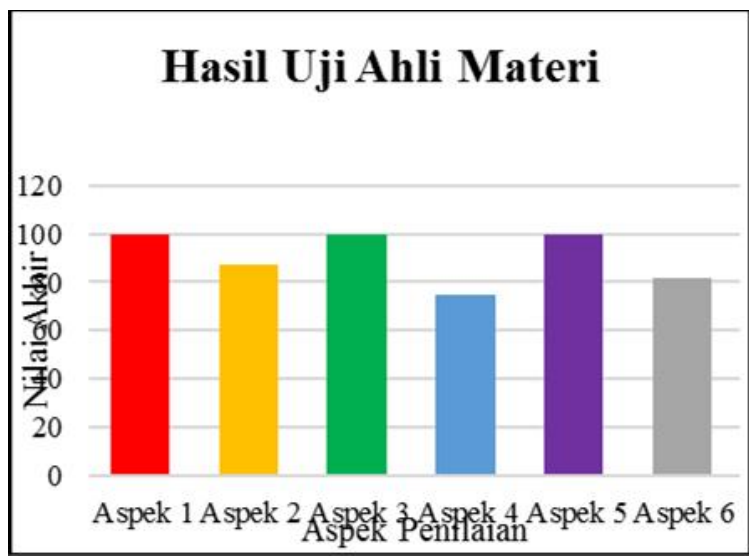

Grafik 2. Hasil Uji Ahli Materi

Berdasarkan grafik di atas, diperoleh keterangan bahwa hasil uji ahli materi pada aspek 1 (aspek akurasi) memperoleh nilai 100 berada pada kategori "Sangat Baik", pada aspek 2 (aspek bahasa) memperoleh nilai 87,5 berada pada kategori "Sangat Baik", pada aspek 3 (aspek membangkitkan motivasi) memperoleh nilai 100 berada pada kategori "Sangat Baik", pada aspek 4 (aspek partisipasi) memperoleh nilai 75 berada dalam kategori "Baik", pada aspek 5 (aspek kebermanfaatan) memperoleh nilai 100 berada pada kategori "Sangat Baik", dan pada aspek 6 (aspek penjelasan materi) memperoleh nilai 81,82 berada pada kategori "Sangat Baik". Sementara itu, diketahui bahwa nilai akhir dari uji ahli materi adalah sebesar 86,85 atau berada pada rentang nilai 76100 sehingga termasuk dalam kategori "Sangat Baik".

Pada tahap selanjutnya, peneliti melakukan perbaikan produk berdasarkan saran/komentar dari masing-masing ahli. Setelah perbaikan selesai dilakukan, peneliti melakukan uji coba produk (uji lapangan) dengan hasil sebagao berikut:

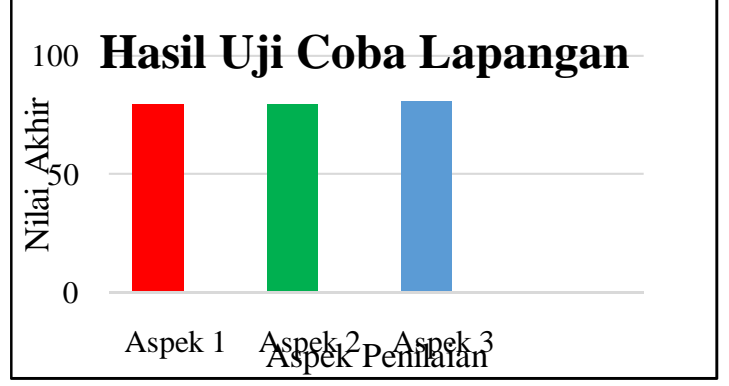

Grafik 3. Hasil Uji Coba Produk (Uji Lapangan) 
Berdasarkan grafik di atas, diperoleh keterangan bahwa uji coba lapangan (uji keterbacaan produk) pada aspek 1 (aspek kualitas desain) memperoleh nilai 79,75 berada pada kategori "Sangat Baik", pada aspek 2 (aspek penjelasan materi) memperoleh nilai 79,73 berada pada kategori "Sangat Baik" dan pada aspek 3 (aspek kualitas materi) memperoleh nilai 80,8 berada pada kategori "Sangat Baik". Sementara itu, diketahui bahwa nilai akhir dari uji coba lapangan (uji keterbacaan produk) adalah sebesar 80,00 atau berada pada rentang nilai $76-100$ sehingga termasuk dalam kategori "Sangat Baik".

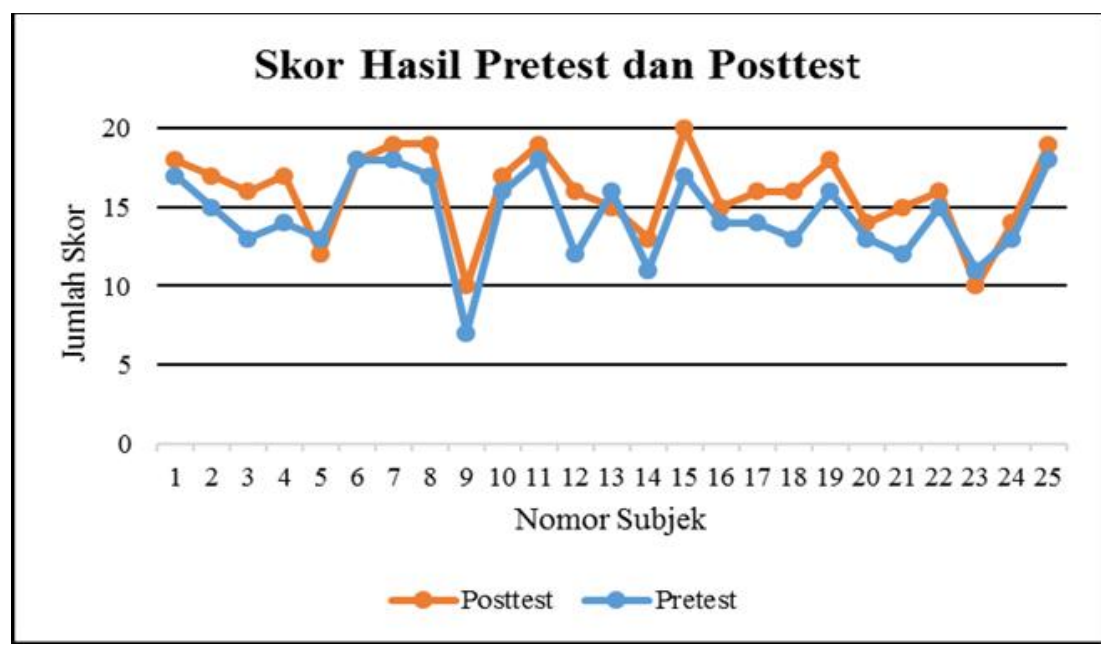

Grafik 3. Skol Hasil Pretest dan Posttest

Grafik di atas menunjukkan hasil uji efektivitas penggunaan modul dalam meningkatkan pemahaman 25 guru BK dalam menyusun program BK komprehensif di SMK. Hasil uji efektifitas modul menunjukkan adanya peningkatan dengan rata-rata skor pretest 14,44 dan rata-rata skor posttest 15,96, dengan selisih skor sebesar 1,52. Kemudian, berdasarkan perhitungan rumus $t$-test diperoleh $\mathrm{t}$ sebesar 5,60, dan setelah dikonsultasikan dengan tabel distribusi $\mathrm{t}$ diperoleh perbandingan $\mathrm{t}_{0,05}<\mathrm{t}_{0,01}<\mathrm{t}$, yaitu $2,08<2,80<5,60$.
Perbandingan ini memiliki arti bahwa penggunaan modul memiliki pengaruh positif (signifikan) baik pada taraf signifikansi $t_{0,05}$ maupun taraf signifikansi $t_{0,01}$. Pada saat sebelum membaca/menggunakan modul, guru BK belum memiliki wawasan yang mendalam tentang cara menyusun program bimbingan dan konseling komprehensif di SMK sehingga belum paham secara utuh. Setelah diberikan modul, maka guru BK dapat mempelajari modul dengan baik dan menyerap materi modul. Hal ini sesuai dengan konsep bahwa modul merupakan bahan belajar 
yang mudah dipelajari oleh segenap kalangan, karena di dalamnya juga disertai latihan soal yang relevan dengan materi modul. Hal ini sebagaimana pendapat Sukmadinata (2013: 165) bahwa "untuk dapat meningkatkan kemampuan guru yang tersebar dalam suatu daerah yang sangat luas membutuhkan bahan latihan atau penataran yang disusun dalam bentuk modul". Akhirnya, telah terbukti bahwa modul penyusunan program bimbingan dan konseling komprehensif di Sekolah Menengah Kejuruan efektif dalam meningkatkan pemahaman guru BK di SMK Negeri se-Kota Yogyakarta tentang cara menyusun program bimbingan dan konseling komprehensif.

Berdasarkan hasil yang diperoleh dari serangkaian tahap pengembangan, maka dihasilkan produk akhir berupa "Modul Penyusunan Program Bimbingan dan Konseling Komprehensif di Sekolah Menengah Kejuruan". Modul ini telah layak untuk digunakan sebagai pedoman bagi guru BK dalam menyusun program bimbingan dan konseling komprehensif di Sekolah Menengan Kejuruan. Modul tersebut diharapkan dapat dipergunakan guru BK dalam mempersiapkan sampai dengan menyusun program bimbingan dan konseling komprehensif yang sesuai dengan kebutuhan siswa serta lingkungannya. Modul ini menjadi media yang efektif dalam meningkatkan pemahaman bagi guru BK kaitannya dengan konsep teoritis dan praktis bimbingan dan konseling komprehensif.

\section{SIMPULAN}

Penelitian tentang pengembangan modul penyusunan program bimbingan dan konseling komprehensif di SMK, mencakup kegiatan perancangan, pengembangan, uji ahli media, uji ahli materi, uji coba lapangan (uji keterbacaan produk), dan uji efektivitas produk). Hasil penelitian menunjukkan hasil uji ahli media memperoleh nilai akhir sebesar 73,44 dengan kategori "Baik". Hasil uji ahli materi memperoleh nilai akhir sebesar 86,85 dengan kategori "Sangat Baik". Sedangkan hasil uji coba lapangan (uji keterbacaan modul) memperoleh skor 80 dengan kategori "Sangat Baik". Hasil uji efektifitas modul menunjukkan adanya peningkatan dengan rata-rata skor pretest 14,44 dan rata-rata skor posttest 15,96, dengan selisih skor sebesar 1,52. Kemudian, berdasarkan perhitungan rumus $t$-test diperoleh $\mathrm{t}$ sebesar 5,60, dan setelah dikonsultasikan dengan tabel distribusi $\mathrm{t}$ diperoleh perbandingan $\mathrm{t}_{0,05}<\mathrm{t}_{0,01}<\mathrm{t}$, yaitu $2,08<2,80<5,60$. Perbandingan ini memiliki arti bahwa penggunaan modul memiliki pengaruh positif (signifikan) baik pada taraf signifikansi $t_{0,05}$ maupun taraf signifikansi $t_{0,01}$. Hal ini menunjukkan bahwa pengembangan modul penyusunan program bimbingan dan konseling di SMK telah terlaksana dan modul ini efektif dalam meningkatkan pemahaman 
guru BK di SMK dalam menyusun program BK komprehensif. Pembahasan materi dalam modul ini masih secara umum, sehingga penelitian selanjutnya dapat lebih mendetail secara khusus membahas komponen program satu per satu. Hasil dari penelitian ini diharapkan dapat digunakan sebagai bahan kajian keilmuan bimbingan dan konseling serta sebahai bahan kajian pembanding pada penelitian selanjutnya.

\section{DAFTAR PUSTAKA}

American School Counselor Association. (2012). The ASCA National Model: A Frame work For School Counseling Program. Third Edition. Alexandria, VA: Author.

Dollarhide. (2011). Comprehensive School Counseling Programs: K-12 Delivery Systems in Action (2nd Edition). Pearson.

Gysbers, N.C. \& Henderson P. (2012). Developing and Managing Your School Guidance and Counseling Program FIFTH Edition. Alexandria : American Counseling Assosiation.

Hasan, S. U. N., \& Bhakti, C. P. (2016). Guidance and Counselling: A Comparison between Indonesia and Malaysia. Scientific Journal of PPI-UKM, 3(6), 267-271.

Juliwantoro. (2016). Profil Tingkat Pemahaman Guru BK Dalam Menyusun Program BK Komprehensif SMK Negeri seKota Yogyakarta. Jurnal Skripsi Bimbingan dan Konseling UAD, September 2016.
Juntika. (2011). Membangun Peradaban Bangsa Indonesia Melalui Pendidikan dan Komprehensif Bernutu. Pidato Pengukuhan Prof. Dr. H. Juntika, M.Pd sebagai Guru Besar/Profesor dalam Bidang Bimbingan dan Konseling Pada Fakultas Ilmu Pendidikan Universitas Pendidikan Indonesia, 15 November 2011.

Mulyatingsih, Endang. (2011). Riset Terapan: Bidang Pendidikan \& Teknik. Yogyakarta: UNY Press.

Nurrahmi, Hesty. (2015).

Kompetensi Profesional Guru Bimbingan dan Konseling. Jurnal Dakwah Alhikmah, Vol. 9, No.1. Pontianak: IAIN Pontianak.

Peraturan Menteri Pendidikan dan Kebudayaan Nomor 111 Tahun 2014 tentang Bimbingan dan Konseling Pada Pendidikan Dasar dan Menengah.

Peraturan Menteri Pendidikan Nasional Nomor 27 Tahun 2008 tentang Standar Kualifikasi Akademik dan Kompetensi Konselor.

Peraturan Menteri Pendidikan Nasional Nomor 70 Tahun 2013 tentang Kerangka Dasar dan Struktur Kurikulum Sekolah Mengah Kejuruan/Madrasah Aliyah Kejuruan.

Sutoyo, Anwar, dkk. (2015). Bimbingan dan Konseling Perkembangan. Semarang: Pasca Sarjana Bimbingan dan Konseling UNNES.

Undang-Undang Nomor 20 Tahun 2003 tentang Sistem Pendidikan Nasional 